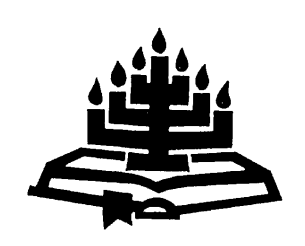

\title{
Die noodsaak van die verrekening van metateoretiese aspekte rakende 'n hermeneutiese benadering tot die Praktiese Teologie
}

\author{
H.J.C. Pieterse \\ Filosofie, Praktiese en Sistematiese Teologie \\ Universiteit van Suid-Afrika \\ PRETORIA \\ E-pos: pietehjc@absamail.co.za
}

\begin{abstract}
The necessity of taking into account metatheoretical aspects pertaining to a hermeneutical approach to Practical Theology
\end{abstract}

This article is part of the project "Metatheoretical assumptions in Practical Theology". Within the theological framework of the project, namely that we view reality as a realm where God is working, and that we interpret praxis from this point of departure, this article discusses our approach to the interpretation of praxis which we see as a hermeneutical moment. Currently there are, among others, empirical, hermeneutical, liberationtheological and narrative approaches to Practical Theology. The author has chosen to discuss the hermeneutical approach to the study of the discipline from a reformed theological perspective. The philosophical-hermeneutical theories and the hermeneutical approach to Practical Theology by Browning, Dingemans, Heitink and Osmer are discussed. From a reformational perspective the conclusion is that we can critically link up with Osmer's approach.

\section{Opsomming}

Die noodsaak van die verrekening van metateoretiese aspekte rakende ' $n$ hermeneutiese benadering tot die Praktiese Teologie

Hierdie artikel vorm deel van die projek "Metateoretiese vertrekpunte in die Praktiese Teologie". Binne die teologiese raamwerk van die projek, naamlik dat ons die werklikheid sien as God wat 
daarin werksaam is en ook die interpretasie van die praksis vanuit ons teologiese invalshoek benader, handel hierdie artikel oor 'n benadering tot die interpretasie van die praksis, wat deur ons as 'n hermeneutiese moment gesien word. Tans bestaan daar onder andere die empiriese, hermeneutiese, bevrydingsteologiese en narratiewe benaderings tot die Praktiese Teologie. Die outeur het gekies om vanuit reformatories-teologiese perspektief die hermeneutiese benadering tot die vak te bespreek. Die wetenskapsfilosofiese teorieë oor die hermeneutiek, en die hermeneutiese benaderings tot die Praktiese Teologie van Browning, Dingemans, Heitink en Osmer word bespreek. Die gevolgtrekking is dat ons vanuit 'n reformatoriese perspektief krities by Osmer se benadering kan aans/uit.

\section{Inleiding}

In die projek "Metateoretiese vertrekpunte in die Praktiese Teologie, word in verskeie opvolgende artikels verantwoording gedoen oor die reformatoriese perspektief en die teologiese lens waardeur ons die omgewing van die praksis en die praksis self waarneem en verstaan. In die eerste fase van die projek word enkele kardinale metateoretiese aspekte geïdentifiseer wat bepalend kan wees vir die wyse waarop 'n navorser se invalshoek, visualisering van die taak en doel van Praktiese Teologie en navorsingsmetodologie geselekteer en ingerig word. Die noodsaak daarvan om die eie navorsing ten opsigte van hierdie metateoretiese faktore te verwoord, word in die eerste fase bespreek. In die tweede fase van die projek word die bepalende invloed van hierdie metateoretiese aspekte geïllustreer deur die aanpak van bepaalde navorsingsprojekte in onder andere Homiletiek, Liturgiek, Kategetiek en Pastorale wetenskap. Die kardinale metateoretiese aspekte wat in fase een geïdentifiseer en bespreek word, sluit die belang daarvan in om die eie benadering te verantwoord ten opsigte van werklikheidsbeskouing, hermeneutiese vertrekpunte, benadering en wetenskapsbeskouing. Hierdie artikel handel oor metateoretiese aspekte rakende 'n hermeneutiese benadering tot die vakgebied van Praktiese Teologie vanuit ons metateoretiese invalshoek. Met die oog op die interpretasie van die praksis word al die veelvoudige komponente van so ' $n$ interpretasie in ag geneem, naamlik van die Skrif, die werklikheid, asook die werklikheid van die praksis wat tans in gebruik is.

Daar is verskillende benaderings tot die beoefening van die Praktiese Teologie en die gevolglike wyse van ondersoek in hierdie vak. Die benaderings kan breedweg onderskei word as ' $n$ basies empiriese benadering (vgl. Van der Ven, 1993), 'n hermeneutiese bena- 
dering (vgl. Browning, 1991; Dingemans, 1996; Heitink, 1993; Osmer, 2008), 'n bevrydingsteologiese benadering (vgl. Cochrane et al., 1991), en 'n narratiewe benadering (vgl. Müller, 2005; Demasure \& Müller, 2006). Die suiwer empiriese benadering in terme van empiriese teologie is versag tot 'n plasing van die empiriese deel van die ondersoek binne 'n hermeneutiese kader soos in die latere werk van Van der Ven (vgl. Van der Ven et al., 2004; Osmer, 2004). Die suiwer hermeneutiese benadering van Dingemans (vgl. Dingemans, 1996) is verbreed tot die insluiting van 'n empiriese of beskrywende (descriptive) aspek van die benadering (vgl. Heitink, 1993; Browning, 1991; Osmer, 2008). Wanneer 'n mens metateoretiese beslissings moet maak oor die reformatoriese benadering tot die vak, dring die navorsingsvraag, die probleem na vore: watter van die benaderings in die vak pas by ons teologiese uitgangspunte? Dit is dus nodig om ons teologiese uitgangspunte te stel oor die perspektief waarmee ons die werklikheid waarneem en verstaan, asook die werklikheid van die bestaande praksis van die kerk en gelowiges. Verder moet die wetenskapsteorieë wat agter jou gekose benadering funksioneer, in ag geneem word. Daarna word die gekose benadering beskryf.

Eerstens word die reformatoriese teologiese uitgangspunte kortliks gestel. In die lig van ons metateoretiese teologiese siening waarmee ons na die werklikheid kyk en die praksis benader, word verantwoording gedoen ten opsigte van die keuse wat vir die hermeneutiese benadering tot die Praktiese Teologie gemaak word. Vervolgens word die filosofies-hermeneutiese teorieë wat as wetenskapsteoretiese onderbou funksioneer, gestel. Laastens word die hermeneutiese benadering beskryf soos toegepas in Praktiese Teologie as vak. Die doel van die artikel is dus om in die lig van ons reformatoriese teologiese perspektief op die Praktiese Teologie metateoreties aan te dui waarom dit deur ons as 'n sinvolle keuse geag word om met ' $n$ hermeneutiese model as benadering tot die vak te werk. Die metode wat in die artikel gebruik word, is literatuurondersoek en 'n kritiese interpretasie daarvan.

\section{Metateoretiese teologiese perspektief}

Geen mens neem die werklikheid waar sonder sekere vooronderstellings en wêreldbeskouings nie. Ten opsigte van 'n empiriese ondersoek in die Praktiese Teologie, skryf Jaco Dreyer (2004:11):

If we look at the history of the social sciences and humanities, we see a vast number of approaches to empirical research. Empirical research (like all academic work) is always done from 
a certain perspective and against the backdrop of certain assumptions and world views.

Hierdie insig geld in alle akademiese werk, ook ten opsigte van die benadering tot 'n dissipline wat 'n mens kies en die wyse waarop jy waarneem en interpreteer. Dit is dus belangrik om die teologiese metateoretiese perspektief aan die begin van 'n ondersoekprojek of 'n artikel in die Praktiese Teologie te stel. Daarom poneer Osmer (2008:58) dat 'n metateoretiese perspektief uit vooronderstellings (assumptions) oor die werklikheid, kennis en wetenskap bestaan.

As reformatoriese praktiese teoloog neem die outeur sy vertrekpunt in die Skrif as die enigste bron van kennis vir die manier waarop God Hom in sy Woord openbaar. Die Skrifkennis is ware kennis van God (Pieterse, 2005:416-418). Die Skrif as die Woord van God is die basis van ons geloof (Naudé, 2005:134-135). Hy is die SkepperGod wat Hom as Verlosser van sondaarmense in Jesus Christus openbaar. Die verlossende werk is gerig op die voleindigende verhouding met ons en ons werklikheid. God tree in 'n verbondsverhouding met ons as verloste sondaars deur ons geloof in Jesus Christus. Hy neem die inisiatief deur sy Woord en Gees. In Jesus Christus openbaar God Hom in die Skrif as die God wat ons tegemoet tree sodat die mens hom/haar coram Deo bevind (Wethmar, 1977:129). God maak ons deel van sy verbond. In hierdie verbondstruktuur wat Hy met ons sluit, is God met ons in 'n verhouding van gemeenskap en kommunikasie. Deur die werking van die Heilige Gees is Hy met ons in ons optrede tot die uitbreiding en die koms van sy koninkryk, wat gerig is op heiligmaking en voleindiging (vir die resiprositiewe, d.i. wederkerige verhouding van die Gees met ons optrede in die Naam van die Here, vgl. Van Ruler, 1969-1973; Bohren, 1974:76 - Er nimmt uns in ein Handeln hinein; vir die koninkryk van God en die geskiedenis, vgl. Van Ruler, 1978:29-38). God is dus dinamies werksaam in ons werklikheid en dit is 'n komplekse, voortdurend-bewegende werklikheid vanweë faktore, motiewe en gebeurlikhede wat daarin 'n rol speel.

Ons verstaan God soos Hy Homself openbaar as Drie-enige God, Vader, Seun en Heilige Gees. In die geskiedenis van die Christelike kerk was daar dikwels mense wat onder invloed van die Hellenisme, God as unitaries wou sien. Calvyn volg egter die Skrifopenbaring en verstaan die één goddelike wese as drie Persone in verhouding. "But in this unity there is a distinction of persons" (Niesel, 1980:58; vgl. ook Baars, 1974:655-660). Die doel van Calvyn se Drie-eenheidsleer, in aansluiting by die Vroeë Kerk, is om die Skrif se boodskap dat God Hom in Jesus Christus in die vlees openbaar het, 
teenoor valse interpretasies te beskerm (Niesel, 1980:57). Trouens, by alle persone wat die unitariese idee voorstaan, word Jesus Christus moeilik as God erken. Die reformatoriese perspektief in aansluiting by die Drie-eenheid van God stel dat Woord en Gees 'n eenheid is daarin dat die Gees die Woord vergesel wanneer dit verkondig word (Pieterse, 1979:92). Die eenheid van Woord en Gees moet egter nie as 'n blywende Woord-immanensie (-inwoning) gesien word nie, want dit sou die vryheid van die Gees inperk. Calvyn het egter klem gelê op die noue verbintenis tussen heilige Skrif, Heilige Gees en prediking (Calvijn, 1956, 1:48 e.v.). God gee sy Gees nie sonder die Woord nie. Inteendeel, die Gees het die outeurs van die Skrif geïnspireer en verlig die interpretasie van diegene wat die Skrif in geloof en gebed lees. Wanneer die Woord verkondig word, vergesel die Gees die Woord. Die Gees werk dus gewoonlik nie buite die Woord om nie, maar in noue verbintenis met die Woord. Wanneer ons die werklikheid en die praksis wat ons ondersoek op 'n hermeneutiese wyse verstaan, werk ons met 'n pneumatologiese invalshoek (vgl. De Wet, 2009), want die Gees is in Christus veranker (vgl. Jonker, 1981). Ons kan ook nie die Skrif verstaan sonder Jesus Christus as die hermeneutiese sleutel nie (Baars, 2004:64-71, 697).

Die aard van Skrifkennis is belangrik vir die interpretasie van die praksis in die vraag of die praksis vanuit ons metateoretiese hoek goed is of nie. Calvyn onderstreep die feit dat ons God en onsself eers waarlik leer ken wanneer ons die Skrif onder die verligting van die Heilige Gees lees (Calvijn, 1956, 1:37-42). Wanneer ons God as Skepper uit die Skrif leer ken, leer ons ook uit die Skrif dat ons sondaars is, en dat ons nodig het om God ook as Verlosser in die Skrif te leer ken. Ons is sondaars, maar in Christus is ons verloste sondaars, gelei in die waarheid deur die Gees. Die aard van Skrifkennis is ook sodanig dat ons in die Skrif leer hoe God teenoor ons is (Baars, 2004:670). Hierdie kennis is by Calvyn soteriologies van aard (Baars, 2004:670-673). Die praksis van die kerk en die gelowiges op alle terreine van die lewe word deur ons reformatoriese geloofstradisie beïnvloed. Ons interpretasie van die komplekse werklikheid geskied in die lig van die Skrif, waarin ons die bediening van die versoening in die liturgie, die prediking, die kategese en die pastoraat beoefen. Die teologiese teorieë wat die praksis onderlê, kan moontlik nie meer relevant vir 'n gegewe konteks funksioneer nie. Die praksis kan ook as blinde praksis funksioneer, sonder refleksie oor die Skrif as kriterium en die verstaan daarvan vir die neerslag in prakties-teologiese teorieë in 'n nuwe konteks. Vanweë hierdie probleme in die praksis is dit nodig om die wisselwerking 
helder te verstaan tussen die Skrif as kriterium waarin die Skrif die primaat is, ons ervaring van God se werking deur sy Woord en Gees in ons lewens, asook die ervaring van die lewe in ons konteks. Die wisselwerking in die dialogiese modus van die verbondsverhouding tussen God en ons het 'n hermeneutiese stempel. Daarom is die aard van Skrifkennis belangrik vir ons interpretasie van die praksis.

Op die voetspoor van Osmer (2008:10) is dit duidelik dat die gedagtes hierbo alles te make het met interpretasie. Die praktiese teoloog moet tydens ' $n$ ondersoek in interpretatiewe interaksie verkeer met die kompleksiteite van die interpretasie van die Skrif binne die heersende praksis, wat weer binne die raamwerk van jou interpretasie van die werklikheid funksioneer. In bogaande komplekse, wisselwerkende verhoudings waarbinne die praktiese teoloog ondersoek moet doen, moet die empiriese beskrywing van die praksis verder geïnterpreteer word in wisselwerking met ons teologiese tradisie. Die teologiese tradisie het die Skrif as kriterium, naamlik ' $n$ teosentriese verstaan van God waarin Christus veranker is, en die verstaan van die mens as 'n begenadigde sondaar. In hierdie interaksie van interpretasie word die prakties-teologiese teorieë wat in die huidige praksis funksioneer, krities betrek. Die ontwikkeling van nuwe of verbeterde praktykteorieë verg egter interpretasie van alle bevindings wat voor die ondersoeker lê. Daarom kies ons in hierdie projek, wat oor metateorieë in die Praktiese Teologie handel, vir 'n hermeneutiese benadering tot die studie van die Praktiese Teologie.

\section{Metateoretiese perspektief ten opsigte van die wetenskapsfilosofiese teorieë oor die hermeneutiek}

In die sfeer van die Kantiaanse epistemologie is voortdurend na 'n objektiewe wyse van wetenskapsbeoefening gesoek, ook in die geesteswetenskappe. Die epistemologiese vraag was dus steeds: Hoe ken ons? Met die werk van Schleiermacher, Dilthey, Heidegger, Gadamer en Ricoeur is 'n nuwe rigting in die wetenskapsfilosofie ingeslaan, naamlik die soeke na 'n werkbare hermeneutiese toepassing in die geesteswetenskappe. Dit is ook vir die Teologie van belang, omdat hermeneutiese filosowe dikwels ook met die interpretasie van tekste werk. Vervolgens word die worsteling van hermeneutiese filosowe kursories aangestip in die soeke na 'n fatsoenlike epistemologie vir die geesteswetenskappe. Die algemene hermeneutiek wat ons van hierdie denkers soos van Gadamer en Ricoeur geërf het, verskaf aan ons 'n bruikbare benadering vir 'n teologiese hermeneutiek. 


\subsection{Schleiermacher en die subjektiewe belewing van die saak van die teks}

Friedrich Schleiermacher (1768-1834) het die subjektiewe interpretasie op 'n teoretiese wyse in die hermeneutiek staangemaak. Sy ontwerp is 'n teologiese reaksie op die filosofie van Kant, binne die konteks van sy tyd. Die objektiewe, altyd-geldige reëls vir die eksegese was volgens sy insig nie meer genoeg nie. Daar moes die aandag in die teologiese hermeneutiek gevestig word op die rol van die leser in die verstaansproses. Die subjektiewe belewing deur die leser van 'n Bybelsteks kan die betekenisgewing grondig verander. Daarmee word die hermeneutiek verhef tot 'n selfstandige onderwerp. Die keuse van sy interpretasieteorie maak die leser 'n integrale deel van die verstaansproses (vgl. Schleiermacher, 1980).

In die lig van Kant se denke aanvaar Schleiermacher dat objektiewe kennis van die bonatuurlike onmoontlik is. Daarom ontwikkel hy die insig dat die religiositeit van die mens 'n eie vermoë het naas die denke en die doen. Die religieuse deurdring die denke en handelings van die mens en bepaal dus die mens se bewussyn. In die bewussyn ervaar die mens ten diepste haar-/homself. Op hierdie bewussyn moet die gelowige refleksie in die teologie konsentreer. By Schleiermacher kry die metafisiese, wat nie objektief geken kan word nie, 'n nuwe betekenis as die religieuse in die subjektiewe belewing; die schlechthinnige Abhängigkeitsgefühl. Hy is van oordeel dat 'n mens deur Einfühlung (empatie) 'n ander (ook die outeur van 'n teks) se gemoed kan verstaan. Die psigologiese interpretasie is noodsaaklik, naas die grammatiese en die historiese, aangesien daardeur kontak gemaak word met die lewensuiting van die outeur. Die leser kan die outeur van die teks se belewing goed begryp, want dit gaan om die saak waarmee die outeur en die leser in hulle eie subjektiewe belewing besig is. Die kloof tussen die teks en die leser word oorbrug deur die algemene menslike natuur waaraan albei deel het. Die verstaan is deur Schleiermacher self tot probleem gemaak (Barth, 1972:425-473; Wethmar, 1977:156; Pieterse, 1979: 20; Vaessen, 1997:46-48). By Schleiermacher val die klem van die spanning tussen leser en teks in die proses van betekenisgewing, feitlik heeltemal op die leser.

\subsection{Dilthey se objektiewe psigologiese hermeneutiek deur die verstaan van die lewenservaring van die leser en dié van die outeur van die teks}

Wilhelm Dilthey (1833-1911) het 'n poging aangewend om die geesteswetenskappe wetenskaplik te begrond. Wat Kant vir die natuur- 
wetenskappe gedoen het, wou hy vir die Geisteswissenschaften doen, naamlik die daarstelling van 'n objektiewe basis vir wetenskaplike ondersoek. Binne hierdie kader het hy aandag aan die hermeneutiek gegee. Die ooreenkoms van die menslike lewe (geleefde lewe, lewenservaring) in die geschichtliche lewe van die leser en dié van die outeur uit die verlede is die middel om die historiese kloof tussen die leser en die teks te oorbrug. Die verstaan is die metode vir hierdie taak.

Dilthey drew upon hermeneutics, especially as it had been developed by Schleiermacher, to bring out what he took to be both the distinctive subject matter and the method of the Geisteswissenschaften, especially as historical reason. (Bernstein, 1989:30.)

Om die menslike lewe objektief te verstaan, neem hy die psigologie in diens as objektiewe uitgangspunt van die geesteswetenskappe. Maar om 'n begrip van die historisiteit van die lewe destyds en vandag te kry, werk hy met objektiewe historiese kennis. Psigologie en geskiedenis kry by Dilthey dieselfde objektiewe status. Die mens druk sy lewenservaring in taal en kultuurgoedere uit wat bestudeer moet word. Dit is die raamwerk van Dilthey se idee van die wetenskaplike benadering in die geesteswetenskappe, wat op gelyke vlak met die natuurwetenskappe kan werk. Teenoor die "verklaar" van die natuurwetenskappe stel hy die "verstaan" van die menslike gees vir die geesteswetenskappe. Dit gaan om die invoelende psigologiese begryp van die gees van die mens. 'n Mens kan belangrike insigte oor die lewe van die mens ken deur verstanend toegang te verkry tot uitdrukkings van die menslike lewe in die verlede deur middel van tekste en ander kultuuruitdrukkings. Die verstanende interpretasie moet dus die oorblyfsels van menslike eksistensie soek wat in die geskrewe Woord vasgelê is. Taal word hier gesien as die objektiewe omhulsel waardeur geboor moet word om die eksistensiële wat in die teks uitgedruk is, vas te stel. Die onderskeid tussen verklaar en begryp lê in die verskil tussen die natuur en die menslike gees, die fisiese en die psigiese.

Dilthey plaas die hermeneutiek dus in die dinamiek van die menslike lewe, wat steeds interpreterend in 'n voordurende samehang voorkom. Die invoeling in die Bybelteks kombineer die aandag vir die strukture van die eie psigiese lewe met die interpretasie van die geobjektiveerde lewensuitings van die outeur van die teks uit die verlede. Dit beteken dat die verstaan van die menslike lewe deur die bemiddeling van sin in die eie lewe en ook sin in die lewe van die verlede geskied. Die leser probeer 'n gelyktydigheid met die lewens- 
uiting van die teks kry. Daarin is die leser in beginsel nie aan tradisie en die vooroordele wat daarmee gepaard gaan, gebonde nie. Die mens is dus met sy verstaanshorison nie eindig nie. Hieraan gee Gadamer aandag. Dilthey vertrek uiteindelik vanuit die posisie van die leser, omdat die eietydse psigiese strukture op die lewensuitings van die verlede geprojekteer word. Bybeltekste word veral benader vanuit die aktuele vrae van die eie tyd (Vaessen, 1997:49-53; Wethmar, 1977:156-157; Pieterse, 1979:20-21; Bernstein, 1989:30, 37).

\subsection{Die wending by Heidegger}

Martin Heidegger (1899-1976) het 'n nuwe fase in die filosofiese hermeneutiek aangekondig. Sy belangrikste werk in hierdie verband is Sein und Zeit (1927). Heidegger se belangstelling lê veral in die vraag na die ontologie (die wysgerige leer omtrent die synde; dit wat bestaan; die strukture waarin die syn tot uiting kom). Sy fundamentele vraag is dus: Waarom is daar iets en nie niks nie? (Hamlyn, 1988:397). Om toegang te kry tot die syn, die bestaande, gaan Heidegger uit van die menslike bestaan, wat hy die Dasein noem (Heitink, 1993:179). Hy maak dus 'n fundamentele onderskeid tussen Sein (syn) en Dasein (syn in die wêreld; om in die wêreld te wees) (Hamlyn, 1988:398). Hierdeur kan die mens homself omtrent sy eie syn of bestaan ondervra. Dit vra vir 'n eksistensiële ontologiese analise van die Dasein (Heitink, 1993:179). So ontwikkel Heidegger 'n faset van die eksistensiële filosofie en 'n hermeneutiese fenomenologie.

Die Dasein word in verskillende fasette oopgelê (vgl. Hamlyn, 1988: 398-399). Die synsvorm van die mens is dié van bewuste en selfbewuste wesens. Die Dasein het dus onvermydelik 'n persoonlike en 'n individuele uitgangspunt. Die mens is in die wêreld geworpe sonder dat ons iets daaraan kan doen. Die Dasein van die mens as individu, die in-die-wêreld-wees, verskaf aan die mens 'n problematiese plek in die wêreld. Dit word gekarakteriseer deur die Sorge, die sorge wat uitstrek na watter objek die mens ook al te doen kry. 'n Belangrike element van Heidegger se opvatting van die Dasein is dat dit tyd omvat. Die mens het 'n tydsbewussyn van verlede, hede en toekoms waarin die toekoms met baie moontlikhede oopstaan. Die toekomsbewussyn bring egter die mens se bewussyn as eindige wesens na vore. Die dood is 'n realiteit. Daardeur word die mens se bestaan gekenmerk deur Angst wat verband hou met die Sorge. Die mens is tydelik en dit is die grond en grens van die menslike bestaan. Die aanvaarding van die dood as realiteit in die mens se bestaan is 'n kenmerk van die mens as outentieke 
wese, van eigenlijkheid (Hamlyn, 1988:399). Hierdeur ontstaan 'n hermeneutiese Vorverständnis wat die lewe oopmaak vir 'n eksistensiële interpretasie (Heitink, 1993:179). Die probleme van die menslike bestaan, die Angst en Sorge, kan positief deur outentieke mense hanteer word.

Heidegger erken nie 'n werklikheid agter of buite die menslike bestaan of die ontologie nie. Daar is geen goddelike wese agter die bestaan van die werklikheid nie. Die teologie werk ook met menslike kategorieë en benut ook die ontologie. Die gevaar vir enige teologie is om die ontologie op filosofiese wyse te verstaan as dat God die Syn is. Dit is nie Bybels nie en skep dan 'n god wat op onpersoonlike wyse handel. Heidegger se ondersoek van die ontologie met die ontwikkeling van die begrip Vorverständnis het egter die filosofiese hermeneutiek in 'n nuwe fase ingelei (vir Heidegger se bydrae tot die filosofiese hermeneutiek, vgl. Bernstein, 1989:113-114).

In aansluiting by die filosofiese hermeneutiek van die voorgangers sedert Schleiermacher, het Gadamer en Ricoeur dit verder gevoer en ook veral aandag gegee aan die verstaansverhouding tussen teks en leser. Die eietydse hermeneutiese insigte het probeer om leser en teks in 'n spanning te plaas waarin sowel die wêreld van die leser as die wêreld van die teks tot hulle reg kom. Die boodskap van die teks kan sinvol geïnterpreteer word vir die eie wêreldervaring van die leser.

\subsection{Hermeneutiek volgens Gadamer en Ricoeur}

\subsubsection{Die insigte van Gadamer}

Gadamer se invloedryke boek het 'n nuwe benadering op die tafel geplaas (vgl. Gadamer, 1975; Engelse vertaling, 1979). Gadamer het sy werk op Heidegger se ontologie gebaseer, naamlik dat die mens se kontekstuele bestaan in die wêreld die basiese voorwaarde is van elke manier om te ken en betekenis aan sy omgewing te kan gee. Die mens kan slegs betekenis gee en betekenis ontvang in die verstaan van enige saak, vanuit die belewing van die wêreld waarin hy/sy as eindige wese geworpe is (vgl Gadamer, 1975:240-251; 1979:225-236). Elke mens het dus 'n eie verstaanshorison. Die verbinding met die verlede (om dit te kan verstaan) lê in die konsep van die Wirkungsgeschichte, die effektiewe geskiedenis of die interpretasiegeskiedenis - dit is die deurwerking in die tradisie van byvoorbeeld 'n Bybelteks (Gadamer, 1975:284-290; 1979:267-274). Die grense tussen die hede en die verlede noem Gadamer horison$n e$ in die effektiewe geskiedenis. Met elke horison hou iets op en 
begin iets nuuts met die interpretasie van mense vanuit 'n nuwe horison. Die oue en die nuwe staan egter nie heeltemal op sigself nie. Wanneer die oue verbygaan, gee dit 'n erfenis deur aan die nuwe. So werk die effektiewe geskiedenis deur in die menslike bestaan oor horisonne heen waar dit telkens geïnterpreteer word en nuwe tradisies ontstaan.

Met die begrip distansiëring, verduidelik Gadamer die dubbelheid wat bestaan in die verhouding tussen die leser en die teks. Die teks is tegelyk onbereikbaar deur die historiese afstand, maar ook teenwoordig. Dit is teenwoordig in die onbereikbaarheid as gevolg van die effektiewe geskiedenis van die teks. Hermeneutiek word dus 'n konstante worsteling tussen afstand en nabyheid, vervreemding en deelname (Gadamer, 1975:275-282; 1979:258-265). Die teks word nie objektief verstaan nie, want die interpreteerder is deel daarvan. Deur die vooroordele van die eie tyd (voorafmenings) en die vreemdheid van die teks wat in die interpretasie ontmoet word, vind 'n kritiese konfrontasie tussen die leser en die teks plaas. Dit is juis in hierdie heen-en-weer van die interpreterende konfrontasie, waarin die verstaan eindelik kom. Die spanning tussen die eie en die vreemde, deur die verstaansproses heen, bewerk 'n horisonversmelting waarin ' $n$ verstaan van die teks se betekenis vir die eie tyd kan geskied (Gadamer, 1975:289-290, 356-366; 1979:274-276, 333341).

Dit is belangrik om te onthou dat verstaan alleen deur taal kan geskied - veral taal as gesprek (Gadamer, 1975:344-360; 1979:325341). In hierdie gesprek is God as sprekende God ook 'n Subjek wat met ons praat.

Die eie vooroordele word in die verstaansproses helder gemaak en krities in ' $n$ ander lig gestel waarin nuwe insigte as betekenis ontvang word. Die vooroordele kan die vooroordele van die eie tyd wees, of dié van die predikant, of ook die vooroordele wat in die gemeente lewe (Vaessen, 1997:57, 59). Vir die eie tyd waaraan ons as 'n voorgegewe feit gebonde is, gebruik Gadamer ook die begrip situasie (Gadamer, 1975:288; 1979:269). Die verstaanshorison hoort ook by die situasiebegrip.

Die verstaan van 'n teks uit die verlede vir die eie tyd begin in die verstaansproses met die vooroordele van die leser (Gadamer, 1975:261-268; 1979:245-253). Hiermee het Gadamer die verhouding van leser-teks in 'n eweredige verhouding op mekaar betrek. Geen mens staan in die lewe as 'n onbeskrewe blad nie, maar het sienings op grond van sy/haar opvoeding, omgewing, kultuur en die 
invloed van die tradisie, byvoorbeeld ons Christelike geloof. 'n Mens sien dinge volgens die insigte van die eie tyd. Niemand kan daarvan loskom nie. Daarom kan ons liewer die vooroordele openlik en bewustelik in die verstaansproses inbring vir toetsing en kritiek. Eers wanneer 'n mens jou eie situasie met sy denke, sienings en probleme goed bedink en helder in die bewussyn plaas, kan jy na die teks gaan waarin kritiese konfrontasie in die verstaansproses plaasvind. Die gevolg daarvan (as dit goed verloop) is gewoonlik nuwe insigte vanuit die teks en 'n nuwe uitkyk op die eie konteks.

In 'n reformatoriese interpretasie van hierdie belangrike insigte van Gadamer, word die hermeneutiese wisselwerking/kritiese konfrontasie tussen teks en leser volgens 'n asimmetriese patroon ingerig. In die reformatoriese benadering het die Skrif die primaat. Die lewende Woord verras ons met nuwe insigte en breek (ten spyte van ons vooroordele) nuwe grond oop - ver bo wat ons kan dink. In 'n reformatoriese interpretasie van Gadamer se begrip van "horisonversmelting", is daar sprake van 'n verruiming van ons horison deur die werking van die lewende Woord, waarin God self aan die woord kom.

\subsubsection{Paul Ricoeur se dialektiek tussen die leser en die teks}

Ricoeur sluit aan by Gadamer op 'n paar punte, maar verdiep die insigte deur sy benadering tot taal (vgl. Ricoeur, 1976). Die leser ontvang betekenis deur die omweg van taal, teken en teks. Taal word as diskoers gesien - die grondbeginsel is die voortgaande dialektiek van struktuur en gebeure. Dit word voltrek binne die simbool in sy verskillende lae van sin, op 'n ander manier in veral die metafoor, maar ook in die taal. Dit gaan om taal as teks en die wêreld wat die teks voor dit uitwerp in 'n oneindige proses van interpretasie en nuwe betekenis. Betekenis ontstaan in die dialektiek van taalsisteem en taalgebeure (Ricoeur, 1976:12).

Wanneer gebeure in die konkrete wêreld deur 'n outeur op skrif gestel word, word die betekenis losgemaak van die gebeure en die outeur - die teks verkry 'n semantiese outonomie (Ricoeur, 1976:

25). Die teks word egter steeds deur die dialektiek van gebeure en betekenis beheers. Trouens, die dialektiek word meer eksplisiet deur skrif. Die teks behou egter dit wat gesê is, die inhoud, 'n proposisie. Juis die selfstandigheid van die teks met die kern van dit wat die teks dra, maak dit oop vir 'n surplus van betekenis wanneer dit deur die leser geïnterpreteer word, en deur die leser nuwe betekenis gegee word. Die proses van tekswording en interpretasie, die oorgang van gesproke taal na geskrewe taal en die oorgang na die 
interpretasie van die teks, geskied deur die prosesse van prefigurasie, konfigurasie en refigurasie (Ricoeur, 1984:76-77). By die refigurasie deur die leser, wat gerig is op toeëiening van wat die teks bied, word betekenis gevind vanuit die wêreld van die teks in die wêreld van die leser, waarin nuwe betekenisse gevind kan word.

In hierdie proses word twee wêrelde met mekaar gekonfronteer die wêreld van die teks en die wêreld van die leser. Tekste met hulle meervoudige betekenisse werp elke keer op 'n ander wyse in verskillende kontekste wêrelde aan lesers voor hulle uit. Verstaan geskied wanneer die leser die ander vreemde self van die teks ontvang, wat deur die teks aan hom/haar aangebied word. Die toeeiening van die eiendomlikheid van die teks, bied jou 'n ander siening van jou situasie, wat jou tot handeling beweeg, of jou 'n nuwe verhaal in jou konteks laat maak vanuit die verhaal van die konteks van die teks.

Leser en teks staan dus in 'n dialektiese verhouding tot mekaar. Albei se leefwêreld is ' $n$ inherente deel van die verstaansproses. 'n Leser kan dus tot 'n vrugbaarder konfronterende dialoog met die teks en sy wêreld kom wanneer die eie konteks bewustelik en op sistematiese wyse verdiskonteer is. Ricoeur se hermeneutiek van suspisie van die eie konteks met sy vooringenome houdings en ideologieë het ten doel om jou 'n oper gemoed te gee om die teks se boodskap te ontvang. Dit help egter ook om jou vooroordele helder en bewustelik raak te sien en te sistematiseer, wat die verstaansproses, soos Ricoeur dit sien, bevorder. Gadamer se uitspraak hou in so 'n geval water: "Prejudices (are) conditions of understanding" (Gadamer, 1979:245).

In die ontwikkeling van die algemene, filosofiese hermeneutiek kan 'n mens in die teologie insigte vir 'n teologiese hermeneutiek verkry. Dit is veral die ontwikkeling van insigte wat by Gadamer plaasgevind het, wat deur praktiese teoloë met vrug in diens geneem is. Ook Ricoeur, wat in baie opsigte by Gadamer aansluit (maar nog meer van die interpretasie van tekste maak), is vrugbaar in prakties-teologiese benaderings toegepas.

\section{Hermeneutiese benaderings tot die Praktiese Teologie}

Verskeie praktiese teoloë het die hermeneutiese benadering in Praktiese Teologie gekies. Dit is ook die keuse van die deelnemers aan hierdie projek. Die volgende persone se ontwerpe sal kortliks aangestip word: Browning, Dingemans, Heitink en Osmer. 


\subsection{Browning}

Don Browning het sy benadering tot die Praktiese Teologie op die hermeneutiese teorie van Gadamer gebou (Browning, 1991:37-45). In sy toepassing vir die teologie van Gadamer se hermeneutiese aanpak, maak hy die wending na die praktiese in die vorm van praktiese wysheid wat hy vir die hele teologie aanwend (vgl. Browning, 1991:34-36). Dit het radikale implikasies.

Historical theology, systematic theology, strategic practical theology, and what I will introduce as descriptive theology all become moments in a more inclusive fundamental practical theology. (Browning, 1991:36.)

Alle teologie is prakties en alle teologie het 'n etiese aspek. Die etiese in sy benadering het te make met Gadamer se interpretasie van phronesis. Wanneer jy iets verstaan, moet jy dit ook doen.

Sy hermeneutiese Praktiese Teologie wat hy 'n kritiese korrelasiebenadering noem, beskou hy as 'n nuwe epistemologiese wending na die konteks waarin die praksis plaasvind en wat met 'n hermeneutiese metode ondersoek moet word (Browning, 1991:2-3, 44). Met die hermeneutiese metode moet die tradisie en die teorie en praktyk in wisselwerking gebring word om die gebeure in die praktyk te kan verstaan en verandering te kan bring. Fundamentele Praktiese Teologie bestaan uit vier ondergeskikte bewegings (submovements), naamlik deskriptiewe, historiese, sistematiese en volle praktiese teologie. Hierdie siening van teologie werk hy dan uit met die voorbeelde van kategese, Christian education, en gemeentelike sorg (congregational care) (Browning, 1991:12, 47-58).

Hy begin 'n ondersoek in die Praktiese Teologie met 'n beskrywing (descriptive move) van die praktyk. Die empiriese metode wat hy gebruik, sluit aan by die kulturele antropologie waarin hy gebruik maak van etnografie en psigologie. Hy noem sy antropologiese beskrywing 'n thick description of practice (Browning, 1991:110-135). Sy werk het egter 'n deeglike filosofiese metateoretiese onderbou.

\subsection{G.D.J. Dingemans}

Dingemans sluit aan by Browning, maar bou sy benadering naas Gadamer ook veral op Ricoeur se hermeneutiek (Dingemans, 1996: 56-57). Hy werk suiwer hermeneuties en ondersoek die praktyk ook op 'n hermeneutiese wyse terwyl hy tog in teorie die kultureel-antropologiese benaderingswyse binne die hermeneutiek as 'n goeie moontlikheid noem. Dingemans wys die handelingswetenskaplike 
benadering, waarin die empiriese ondersoek voorkom, sterk af. Hy het ' $n$ reformatoriese benadering in sy werk en dit word deur 'n pneumatologiese invalshoek gestempel wat as 'n teologiese lyn in sy werk loop (vgl. Dingemans, 2000).

Hy sien sy hermeneutiese benadering as 'n prakties-teologiese korrelasieteorie waarin hy ook 'n brug wil slaan tussen die kerk en die eietydse konteks van 'n moderne samelewing deur middel van die interpretasie van die evangelie in sy Nederlandse konteks. Sy hermeneutiese metode in die praktyk word goed geïllustreer in die proefskrif van Vaessen (1997). Hierin werk hy met Ricoeur se hermeneutiek om preke te analiseer. Hy probeer in die analises om die hermeneutiese uitgangspunte en praktyk van die predikers in die preke vas te stel.

\subsection{G. Heitink}

Heitink (1993) is 'n gereformeerde praktiese teoloog met 'n wye kennis van die teologie, die filosofie en die geskiedenis van die teologie. Hy werk met Gadamer en Ricoeur se hermeneutiese benaderings waaraan hy 'n eie stempel gee met sy ontwerp van Praktiese Teologie as teologiese handelingswetenskap in diens van die evangelie (Heitink, 1993:105-292). Hierin werk hy met 'n hermeneutiese perspektief waarin sy prakties-teologiese interpretasieteorie 'n pneumatologiese uitgangspunt het (Heitink, 1993:187-194). Hy werk verder met 'n strategiese perspektief en 'n empiriese perspektief in die ondersoekproses in die Praktiese Teologie (Heitink, 1993:195-230).

Hy dek veral drie terreine in sy beskouing van prakties-teologiese ondersoek waarin die evangelie sinvol gekommunikeer moet word: die individu, die groep en die gemeente, en die samelewing. Heitink se aanpak van ' $n$ hermeneutiese benadering in ' $n$ handelingswetenskaplike model, met empiriese ondersoek as 'n onderdeel van die navorsingsproses, is deur talle reformatoriese praktiese teoloë aanvaar en beoefen.

\subsection{R.R. Osmer}

Osmer (2008) sluit aan by Browning en Van der Ven (1993; vgl. ook Osmer, 2004) in 'n hermeneutiese benadering tot die Praktiese Teologie (Osmer, 2008:20-21). Soos Browning gebruik hy die hermeneutiek van Gadamer as hermeneutiese metateorie (Osmer 2008: 22-23). Hy het die hermeneutiese benadering in die Praktiese Teologie verfyn en die voorafgaande bydraes tot hierdie benadering op ' $n$ sinvolle wyse geïntegreer. Dit beteken dat hy konsekwent met inter- 
pretasie werk, maar ook 'n wye spektrum van kennis van die praktyk in 'n kontinuum inbou - wisselend van informele aandag gee deur priesterlike luister, tot by formele aandag gee aan die praksis deur empiriese ondersoek - veral deur kwalitatiewe ondersoeke (Osmer, 2008:37). Binne ' $n$ hermeneutiese benadering is kwalitatiewe ondersoeke die mees paslike wyse van empiriese ondersoek.

Osmer werk met vier take van prakties-teologiese interpretasie in die Praktiese Teologie. Hy is van oordeel dat die vier take van prakties-teologiese interpretasie 'n soort konsensus vorm te midde van die heersende diversiteit in benaderings tot die vak. Die vier take is: "The descriptive task ... The interpretative task ... The normative task ... The pragmatic task" (Osmer, 2008:4-11). Die vier take hou met mekaar verband en speel voortdurend op mekaar in. Met die beskrywing van die vier take het Osmer die jarelange probleem van die gapings tussen die subdissiplines van die vak, waarin elkeen op 'n eie wyse werk, oorbrug (Osmer, 2008:12-17). Hy het ook met sy aanpak die kloof tussen akademiese Praktiese Teologie en die praktyk van diegene in die bediening oorbrug. Hy gaan konsekwent uit van die praksis van die gemeente.

Osmer is 'n reformatoriese teoloog. Sy aanpak is deur en deur teologies in die sfeer van die spiritualiteit van almal wat met die praksis te make het. Hy gebruik 'n reformatories-teologiese metateorie wat sy hele ontwerp vir prakties-teologiese interpretasie bepaal.

As theologians in the Reformed tradition refelected on the many ways the New Testament portrays the themes of promise and fulfillment and God's new covenant in Christ, they brought them together in the concept of the threefold office of Christ ... Building on the tradition of the threefold office, I developed a practical theology of leadership in which the four tasks of practical theological interpretation are portrayed as facilitating the congregation's participation in Christ's priestly, royal, and prophetic mediation of salvation. (Osmer, 2008:28.)

As reformatoriese praktiese teoloë kan ons krities by Osmer se benadering aansluit as ' $n$ omvattende hermeneutiese benadering tot die studie van die Praktiese Teologie, asook met gebruikmaking van insigte van byvoorbeeld Dingemans en Heitink. Wat vir ons by Osmer se hermeneutiese aanpak belangrik is, is die manier waarop hy die praktiese teoloog se navorsing pneumatologies in die priesterlike, profetiese en koninklike ampte van Christus anker. Die praktiese teoloog laat hom in sy hermeneutiese omgaan met die praksis deur die Gees van Christus lei, sodat hy die praksis as 't ware deur 
die oë van Christus en met sy gesindheid waarneem. Hierdie Christus-geankerde spiritualiteit gee daaraan gevolg dat die basiese take van praktiese teologie deur Osmer soos volg ingerig word:

descriptive task of priestly listening in a spirituality of presence (Osmer 2008:33);

interpretative task in a spirituality of sagely wisdom (Osmer 2008:81);

normative task in a spirituality of prophetic discernment (Osmer 2008:135);

pragmatic task in a spirituality of servant leadership (Osmer 2008:183).

Dit is belangrik dat ons voordurend selfrefleksie vanuit ons teologiese perspektief moet toepas. 'n Mens moet vasstel of jou eie vooroordele en die insigte van diegene in die praksis nie vir God se vernuwende handelinge, met die verrassende nuwe dimensies van sy genade in die praksis, hindernisse opwerp nie (vgl. De Wet, 2009: 248).

\section{Slot}

Tussen die verskillende benaderings tot die Praktiese Teologie is vanuit 'n reformatoriese teologiese perspektief 'n hermeneutiese benadering tot die studie van die vak gekies. In die lig van die bespreking in die artikel, kan 'n mens tot die konklusie kom dat ons in verantwoording van ons metateoretiese keuse om Praktiese Teologie vanuit ' $n$ hermeneutiese benadering te beoefen, krities by die ontwerp van Osmer asook met insigte van Dingemans en Heitink sou kon aansluit.

\section{Geraadpleegde bronne}

BAARS, A. 2004. Om Gods verhevenheid en zijn nabijheid: de Drie-eenheid bij Calvijn. Kampen: Kok.

BARTH, K. 1972. Protestant theology in the nineteenth century. London: SCM. BERNSTEIN, R.J. 1989. Beyond objectivism and relativism. Oxford: Blackwell. BOHREN, R. 1974. Predigtlehre. München: Chr. Kaiser Verlag.

BROWNING, D.S. 1991. A fundamental practical theology. Minneapolis: Fortress.

CALVIJN, J. 1956. Institutie. Deel 1. Vertaal deur A. Sizoo. Delft: Meinema.

DE WET, F.W. 2009. Die implikasies van 'n pneumatologies-bepaalde teoretiese raamwerk vir navorsingsmetodologie in prakties-teologiese wetenskapsbeoefening. In die Skriflig, 43(2):227-250. 
DEMASURE, K. \& MÜLLER, J. 2006. Perspectives in support of the narrative turn in pastoral care. Nederduitse Gereformeerde teologiese tydskrif, 47(3 \& 4):410-419.

DINGEMANS, G.D.J. 1996. Manieren van doen: inleiding tot de praktische theologie. Kampen: Kok.

DINGEMANS, G.D.J. 2000. De stem van de Roepende: Pneumatheologie. Kampen: Kok.

DREYER, J.S. 2004. The research challenge: doing empirical research in theology: only study guide for CMM305-X. Pretoria: University of South Africa.

GADAMER, H-G. 1975. Wahrheit und Methode. 4. Auflage. Tübingen: Mohr.

GADAMER, H-G. 1979. Truth and method. Trans. by W. Glen-Doepel. London: Sheed \& Ward.

HAMLYN, D.W. 1988. Westerse filosofie: een geschiedenis van het denken. Utrecht: Uitgeverij Het Spectrum.

HEITINK, G. 1993. Praktische Theologie: geschiedenis, theorie, handelingsvelden. Kampen: Kok.

JONKER, W.D. 1981. Die Gees van Christus. Pretoria: NG Kerkboekhandel.

NAUDË, P. 2005. Geesgedrewe gelowiges: Christene met blydskap - kerke wat groei. Wellington: Lux Verbi.

NIESEL, W. 1980. The theology of Calvin. Trans. by H. Knight. Grand Rapids: Baker.

OSMER, R.R. 2004. Johannes Van der Ven's contribution to the new consensus in Practical Theology. (In Hermans, C.A.M. \& Moore, M.E., eds. Hermeneutics and empirical research in practical theology: the contribution of empirical theology by Johannes A. van der Ven. Leiden: Brill. p. 149-167.)

OSMER, R.R. 2008. Practical Theology: an introduction. Grand Rapids: Eerdmans.

PIETERSE, H.J.C. 1979. Skrifverstaan en prediking. Pretoria: NG Kerkboekhandel.

PIETERSE, H.J.C. 2005. Die rol van Godskennis in die ontmoetingsgebeure met God in die prediking. In die Skriflig, 43(2):409-422.

RICOEUR, P. 1976. Interpretation theory: discourse and the surplus of meaning. Fort Worth: The Texas Christian University Press.

RICOEUR, P. 1984. Time and narrative. Vol. 1. Chicago: University of Chicago Press.

SCHLEIERMACHER, F.D.E. 1980. Der Christliche Glaube. Teilbände 1 \& 2. Herman Peiter, Hrsg. Berlin: De Gruyter.

VAESEN, J.C. 1997. Tussen Schrift en preek. Kampen: Kok.

VAN DER VEN, J.A. 1993. Practical Theology: an empirical approach. Kampen: Kok.

VAN DER VEN, J.A., DREYER, J.S. \& PIETERSE, H.J.C. 2004. Is there a God of human rights? The complex relationship between human rights and religion: a South African case. Leiden: Brill.

VAN RULER, A.A. 1969-1973. Theologish werk. Bd. 1-4. Nijkerk: Callenbach.

VAN RULER, A.A. 1978. Verwachting en voltooiing. Nijkerk: Callenbach.

WETHMAR. C.J. 1977. Dogma en verstaanhorison. Amsterdam: Rodopi. 


\section{Kernbegrippe:}

hermeneutiek, wetenskapsfilosofiese teorieë oor

Praktiese Teologie, hermeneutiese benadering tot reformatoriese perspektief

verstaan, metateoretiese invloed op

\section{Key concepts:}

philosophical hermeneutical theories

Practical Theology, hermeneutical approach to reformed perspective

understanding, metatheoretical influence on 
